\title{
Effect of Potassium Sulphate on the Growth and Uptake of Nutrients in Wheat (Triticum aestivum L.) Under Salt Stressed Conditions
}

\author{
Abida $\operatorname{Kausar}^{1} \&$ Munazza Gull ${ }^{2}$ \\ ${ }^{1}$ Department of Botany, GC University, Faisalabad, Pakistan \\ ${ }^{2}$ Biochemistry Department, Faculty of Science, King Abdulaziz University, Jeddah, Kingdom of Saudi Arabia \\ Correspondence: Munazza Gull, Biochemistry Department, Faculty of Science, King Abdulaziz University, \\ 42805, Jeddah, Kingdom of Saudi Arabia. E-mail: munagull@hotmail.com
}

\author{
Received: May 19, 2014 Accepted: June 8, 2014 Online Published: July 15, 2014 \\ doi:10.5539/jas.v6n8p101 URL: http://dx.doi.org/10.5539/jas.v6n8p101
}

\begin{abstract}
Wheat is cultivated throughout the world to meet the needs of food and feed and industrial raw material in several countries. The salinity has been confirmed as main constrain of crop production and major threat to the agriculture. There is a need to increase the wheat production in marginalized soils. Different strategies have been adopted to increase the crop productivity in the world. During the current study effect of potassium sulphate was investigated for crop production in the salt stressed areas. Different application rate of $\mathrm{K}_{2} \mathrm{SO}_{4}$ (i. e., $50,100,150$, $200 \mathrm{mM}$ ) under $150 \mathrm{mM} \mathrm{NaCl}$ stress were used. It has been observed that the application of $\mathrm{K}_{2} \mathrm{SO}_{4}$ has increased the biomass production irrespective of the rate of application. The application of $200 \mathrm{mMK}_{2} \mathrm{SO}_{4}$ proved to be the best to increase the maximum biomass in saline environment. It was also observed that the use of fertilizer has also increased the uptake of essential nutrients like potassium, calcium, magnesium and phosphorus in saline soils.
\end{abstract}

Keywords: wheat, $\mathrm{NaCl}$, biomass production, sodium, potassium, calcium, nitrogen and phosphorus

\section{Introduction}

Wheat is cultivated all over in the world. It is the oldest and most important of the cereal grains in the world (Ashraf et al., 2013). In the last two decades, the role of wheat has increased especially in the developing countries. It is well grown crop in temperate climates where rainfall is $30-90 \mathrm{~cm}$. Areas which remains warm and moist are not suited but sandy loams and well-drained clay loam soils are suitable for wheat production (Jessop \& Stewart, 1983; Kausar et al., 2014). The best temperature for the seed and development growth ranges from 20-30 ${ }^{\circ} \mathrm{C}$. Some factors such as sufficient rainfall and adequate phosphate fertilizers are required to increase the growth and elongate the root system for the absorption of water (Ashraf et al., 2013).

Salinity is a major abiotic stress in the world which inhibits the growth and development of plants all over in the world (Kosova et al., 2013; Kausar \& Gull, 2014). Crop production loss is the billions of dollars every year because of salinity and sodicity. Under higher salt concentrations, plants take up more toxic ions as compared to the normal soil conditions and consequently the concentration of these ions becomes higher inside the tissues so the osmotic potential become more negative and reduce the plant growth and development (Akhtar et al., 2013). As a result the plants suffer from nutritional imbalance. The increased in the concentration of $\mathrm{NaCl}$ decreases the ionic concentrations of Mg, Ca and K (Han et al., 2014; Gupta \& Huang, 2014). Plant development relies on the rate of photosynthesis. The abiotic stresses that influence the plant development also have a negative response on photosynthesis (Gupta \& Huang, 2014). The severity of the salinity depends upon the concentration of salts on a typical plant species, lower concentrations of salts have the ability to increase the rate of photosynthesis and thus the process of photosynthesis is badly affected (Razmjoo et al., 2008). Salinity increases by the use of poor quality or contaminated water, which shows negative effects on the salt sensitive crops (Ashraf et al., 2013). The vegetative stage is more sensitive to salinity (Hu \& Schmidhalter, 2005). There are two phases of growth after the application of salinity. In the first phase of growth, salinity showed the response quickly and reduce the growth within minutes. In second phase of the growth, salinity showed their effect within days/weeks (Gupta \& Huang, 2014). Several scientists summarized that salinity decreased the root, shoot and total dry biomass of the plants (Ebrahimi et al., 2012). Under saline conditions, water potential is disturbed which causes ionic imbalance that reduce the agricultural crop productivity. The reduction of plant growth is actually depends on severity and 
levels of the salinity (Kausar et al., 2012).

These nutrients deficiencies created by the salinity may reduce by the addition of fertilizers. Potassium plays an important role in the stress physiology (Krauss, 2003; Gupta \& Huang, 2014). Some essential food nutrients such as potassium, nitrogen and phosphorus are important in salt affected soil (Noaman, 2004). It is estimated that potassium occupied a critical position for the wheat physiological requirements (Saifullah et al., 2002) Potassium is essential nutrient and its availability controls many biochemical and physiological responces in plants (Wang et al., 2013). Presence of potassium plays essential roles in various enzyme activation, photosynthesis, proteion synthesis, osmoregulation, Energy transfer, stomatal movement, cation-anion balance and stress resistance (Ashraf et al., 2013; Wang et al., 2013). The fertility of soils may be enhanced by decreasing salinity and proper management of soil (Idrees et al., 2004). Uptake of $\mathrm{K}^{+}$over $\mathrm{Na}^{+}$develops a more efficient system in the salt tolerant crops (Wenxue et al., 2003; Kausar et al., 2014).

Potassium is a macronutrient element which is required for higher concentration for the growth of plants. It plays an important role in the activation of enzyme, stomata opening and closing, tropisms, photosynthesis (Golldack et al., 2003). It helps to maintain the osmotic adjustment more than $\mathrm{Na}^{+}$and $\mathrm{Cl}^{-}$in the plants under saline conditions (Ashraf \& Sarwar, 2002; Kausar et al., 2014). Several scientists stated that stomata close during potassium deficiency, which reduce the ability of photosynthesis in crop plants. Studies have been reported on the effect of potassium on growth and production of of wheat (Mesbah, 2009).

Keeping in view the importance of potassium under salt stressed conditions the present research was carried out to determine the effect of potassium sulphate to alleviate the effect of salinity ion the growth and nutrient uptake of wheat crop.

\section{Materials and Methods}

Different levels of potassium sulphate $\left(\mathrm{K}_{2} \mathrm{SO}_{4}\right)$ were applied in a sand culture to mitigate the growth and yield of wheat crop under salinity stress.

\subsection{Seed Material}

Healthy seeds of almost similar size of two wheat genotypes i.e., NAYAB-11 and MILLAT-11 were grown in this experiment.

\subsection{Experimental Layout}

The experiment was conducted in pots (diameter; $35 \mathrm{~cm}$ ) filled with $12 \mathrm{~kg}$ washed sand and laid out in a completely randomized block design with four treatments of potassium sulphate. Each treatment has three replications. The seeds were sown in 1/2 strength of Hoagland's nutrient solution in a sand culture. After one week of the germination seedlings were subjected to $150 \mathrm{mM} \mathrm{NaCl}$ stress. There was also a control. After two weeks of sowing the both varieties of wheat were subjected to different levels of potassium sulphate i.e. $50 \mathrm{mM}$, $100 \mathrm{mM}, 150 \mathrm{mM}$ and $200 \mathrm{mM}$.

Table 1. Different levels of potassium sulphate at $150 \mathrm{mM}$ of $\mathrm{NaCl}$ stress

\begin{tabular}{lll}
\hline Treatments & $\mathrm{NaCl}$ Concentrations & $\mathrm{K}_{2} \mathrm{SO}_{4}$ Concentrations \\
\hline $\mathrm{T}_{0}$ (control) & $0 \mathrm{mM}$ & $0 \mathrm{mM}$ \\
$\mathrm{T}_{1}$ & $150 \mathrm{mM}$ & $0 \mathrm{mM}$ \\
$\mathrm{T}_{2}$ & $150 \mathrm{mM}$ & $50 \mathrm{mM}$ \\
$\mathrm{T}_{3}$ & $150 \mathrm{mM}$ & $100 \mathrm{mM}$ \\
$\mathrm{T}_{4}$ & $150 \mathrm{mM}$ & $150 \mathrm{mM}$ \\
$\mathrm{T}_{5}$ & $150 \mathrm{mM}$ & $200 \mathrm{mM}$ \\
\hline
\end{tabular}

The pots were re-positioned randomly occasionally. 


\subsection{Physiochemical Characteristics of Irrigation Water}

The irrigation water was analyzed for relevant characteristics:

\begin{tabular}{|c|c|}
\hline Parameters & Values \\
\hline $\mathrm{EC}(\mu \mathrm{S} / \mathrm{cm})$ & 681 \\
\hline $\mathrm{pH}$ & 7.66 \\
\hline $\mathrm{Ca}\left(\mathrm{meq} \mathrm{L}^{-1}\right)$ & 4 \\
\hline $\operatorname{Mg}\left(\right.$ meq L- $\left.{ }^{1}\right)$ & 5 \\
\hline $\mathrm{CO}_{3}\left(\mathrm{meq} \mathrm{L} \mathrm{L}^{-1}\right)$ & - \\
\hline $\mathrm{HCO}_{3}\left(\mathrm{meq} \mathrm{L} \mathrm{L}^{-1}\right)$ & $4-6$ \\
\hline $\mathrm{Cl}^{-}\left(\right.$meq L $\left.\mathrm{L}^{-1}\right)$ & $5-6$ \\
\hline $\mathrm{Na}^{+}\left(\mathrm{mg} \mathrm{kg}^{-1}\right)$ & 60 \\
\hline $\mathrm{K}^{+}\left(\mathrm{mg} \mathrm{kg}^{-1}\right)$ & $3-4.0$ \\
\hline
\end{tabular}

\subsection{Plant Analysis}

Six wheat plants from each treatment were harvested after 120 days and data for shoots and roots lengths and fresh weights were recorded. The plants were oven-dried at $65{ }^{\circ} \mathrm{C}$ for 48 hours to determine dry plant biomass. Plants shoots and roots were analyzed for sodium $(\mathrm{Na})$, potassium $(\mathrm{K})$, calcium $(\mathrm{Ca})$, nitrogen $(\mathrm{N})$ and phosphorus (P). For this purpose ground dried material $(0.5 \mathrm{~g})$ was digested in concentrated $\mathrm{H}_{2} \mathrm{SO}_{4}$ in digestion tubes (Wolf, 1982). The extract of the samples was filtered and diluted to the volume of $50 \mathrm{~mL}$ to determine $\mathrm{K}$, $\mathrm{Na}, \mathrm{Ca}, \mathrm{P}$ and N. Sodium and K was determined using flame photometer (Jenway PFP 7). Phosphorus (P) was determined by a spectrophotometer (Jackson, 1962). Nitrogen was estimated by digesting dry plant material through $\mathrm{H}_{2} \mathrm{SO}_{4}$ and $\mathrm{H}_{2} \mathrm{O}_{2}$ method using micro-Kjeldhal method (Bremner, 1965).

\subsection{Statistical Analysis}

Data were analyzed statistically using STATISTICA Computer Program. Least Significant Difference test at 5\% probability level was used to differentiate means (Steel et al., 1997).

\section{Results and Discussion}

\subsection{Shoot and Root Lengths}

Shoot length of wheat cultivars (NAYAB-11 and MILLAT-11) was significantly affected by the salt stress. It was higher in plants growing in control $(34.317 \mathrm{~cm})$ than saline conditions $(20.333 \mathrm{~cm})$. Application of potassium significantly enhanced shoot length of both wheat cultivars under saline conditions. The length progressively increased with increasing potassium level. Maximum length was observed at $200 \mathrm{mM} \mathrm{K}_{2} \mathrm{SO}_{4}$. Minimum shoot length was noted in $150 \mathrm{mM} \mathrm{NaCl}$ salt concentration (Figure 1a). Maximum shoot length was recorded in NAYAB-11 at $200 \mathrm{mM} \mathrm{K} \mathrm{SO}_{4}$ followed by $150 \mathrm{mM}, 100 \mathrm{mM}$ and $50 \mathrm{mM}$. Maximum decrease (48.6\%) was recorded at $150 \mathrm{mM} \mathrm{NaCl}$ stress. While minimum decreased (11.1\%) was observed at $200 \mathrm{mM} \mathrm{K}_{2} \mathrm{SO}_{4}$ in both NAYAB-11 and MILLAT-11 genotypes under salt stress conditions (Figure 1a). Interaction between treatment and varieties were also significant. Both wheat varieties significantly had lower shoot length under saline conditions than that of normal conditions. Both varieties responded positively to potassium fertilizer under saline conditions. In both varieties of wheat shoot length increased progressively with increasing potassium level (Table 2). 
Table 2. Mean squares from analysis of variance (ANOVA) of data for different levels of $\mathrm{K}_{2} \mathrm{SO}_{4}$ on length, fresh and dry weights of both shoots and roots of two wheat genotypes at $150 \mathrm{mM}$ of $\mathrm{NaCl}$ stress

\begin{tabular}{cccccccc}
\hline SOV & df & Shoot length & Root length & $\begin{array}{c}\text { Shoot fresh } \\
\text { weights }\end{array}$ & $\begin{array}{c}\text { Root fresh } \\
\text { weights }\end{array}$ & $\begin{array}{c}\text { Shoot dry } \\
\text { weight }\end{array}$ & $\begin{array}{c}\text { Root dry } \\
\text { weight }\end{array}$ \\
\hline Treatment & 5 & $174.594 * * *$ & $75.6608 * * *$ & $0.81787 * * *$ & $0.25645^{* * *}$ & $0.46355^{* * *}$ & $194.98^{* * *}$ \\
Variety & 1 & $117.722^{* * *}$ & $28.2492^{* * *}$ & $0.48534 * * *$ & $0.07022^{* * *}$ & $76.85^{* * *}$ & $116.26^{* * *}$ \\
T x V & 5 & $5.99 * *$ & $2.145 \mathrm{~ns}$ & $0.01276^{* *}$ & $0.00168 \mathrm{~ns}$ & $0.74 \mathrm{~ns}$ & $0.67 \mathrm{~ns}$ \\
Error & 24 & 1.454 & 1.0255 & 0.00212 & 0.00073 & & \\
Total & 35 & & & &
\end{tabular}

A number of factors involve lowering the crop growth and yield, such as drought, salinity, and high temperatures (Bray et al., 2000; Wang et al., 2013). Salinity decreased the plant growth and development (Gupta \& Huang, 2014). Decrease in lengths of plants was by the effect of salinity also observed by a number of investigators (Khan, 2010; Ashraf et al., 2011; Ali et al., 2012). Similar investigations were also reported by kausar et al., 2012). They find out that lengths of plants were adversely affected by salinity stress. Growth of wheat may reduced by lower fixation of carbon dioxide, reduced stomatal conductance, photochemical and biochemical capacity or combinations of all other factors in stress environments (Khan \& Panda, 2008).

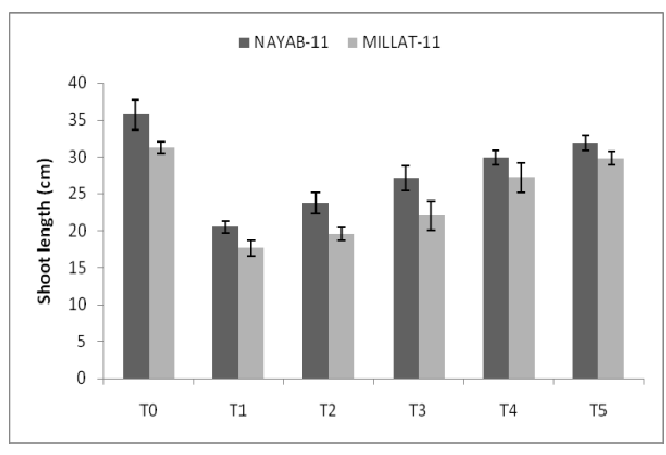

(a)

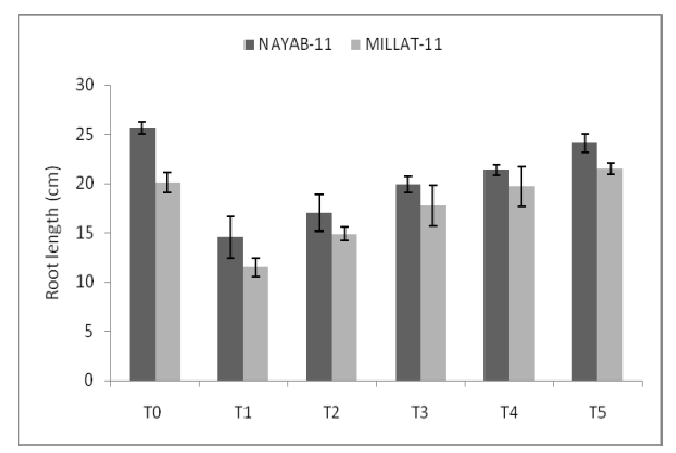

(b)

Figure 1. Effect of different levels of $\mathrm{K}_{2} \mathrm{SO}_{4}$ on length of shoots (a) and roots (b) of two wheat genotypes at 150 $\mathrm{mM}$ of $\mathrm{NaCl}$ stress

Root length of both genotypes affected significantly by salt stress. Maximum root length $(21.862 \mathrm{~cm})$ was observed in plants growing under controlled conditions than that of growing under saline conditions $(12.333 \mathrm{~cm})$ A significant reduction in root length was observed in both genotypes of wheat but higher reduction was recorded in MILLAT-11 under salinity conditions. Potassium application enhanced the root length significantly of both wheat genotypes. Both genotypes of wheat showed different sort of response by the application of potassium (Figure 1b).

Application of potassium slightly increased root length at $50 \mathrm{mM} \mathrm{K} \mathrm{SO}_{4}$ in NAYAB-11 followed by MILLAT-11 under saline conditions. However, maximum increase was observed at $200 \mathrm{mM} \mathrm{K}_{2} \mathrm{SO}_{4}$ in NAYAB-11 than MILLAT-11 under salt stress conditions. Maximum reduction (66.5\%) was showed in MILLAT-11 and NAYAB-11 genotypes at $150 \mathrm{mM} \mathrm{NaCl}$ stress, while minimum reduction $(22.7 \%)$ was recorded in both genotypes at $150 \mathrm{mM} \mathrm{NaCl}$ and $200 \mathrm{mM} \mathrm{K}_{2} \mathrm{SO}_{4}$ (Figure 1b).

Varieties $\mathrm{x}$ treatment interaction were showed non significant results. Under salt stress conditions, both varieties of wheat had lower root length. However, both NAYAB-11 and MILLAT-11 varieties responded positively to potash fertilizer under salinity conditions, and it also increased significantly with increasing level of potassium (Table 2). The reduction in root lengths by the application of salt stress was also reported by Kausar et al. (2012) and Ashraf et al. (2013). A number of other researcher also depicted similar results (Irshad et al., 2002; Ali et al., 2012; Kausar \& Gull, 2014). However, it has been observed that by the application of Potassium sulphate the 
effect of salt stress was alleviated on the lengths of roots. Same was reported by Ashraf et al. (2013) and Tzortzakis (2010) that supplementary potassium reduced the effects of salt stress on the growth of plants (Wang et al., 2013).

\subsection{Shoot and Root Fresh Weights}

Data showed that maximum shoot fresh weight was observed in NAYAB-11 followed by MILLAT-11 in controlled plants. Salinity decreased the shoot fresh weight significantly and least value $1.25 \mathrm{~g}$ was recorded in MILLAT-11 genotypes at $150 \mathrm{mM} \mathrm{NaCl}$. In shoot fresh weight application of potassium indicates the varying effect due to different levels of potassium (Figure 2a).

Whereas maximum shoot fresh weights were determined at the level of $200 \mathrm{mM} \mathrm{K}_{2} \mathrm{SO}_{4}$ under saline medium than other treatments of salinity and potassium. Potash fertilizer mitigates the adverse effect of salinity and plants grown better under saline conditions. Maximum reduction (53.5\%) was observed in MILLAT-11 at 150 $\mathrm{mM}$ sodium chloride stress, i.e. MILLAT showed to be almost salt sensitive plants in shoot fresh weight. Minimum reduction (21.42\%) was recorded in MILLAT-11 at $200 \mathrm{mM} \mathrm{K} 2 \mathrm{SO} 4$ under saline conditions (Figure 2a). Interaction between varieties and treatments showed significant, because potassium and salinity showed significant effect on shoot fresh weight of both wheat genotypes (Table 2).

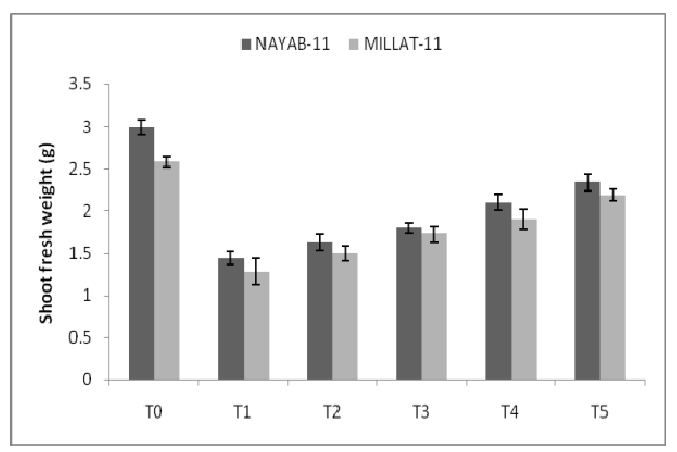

(a)

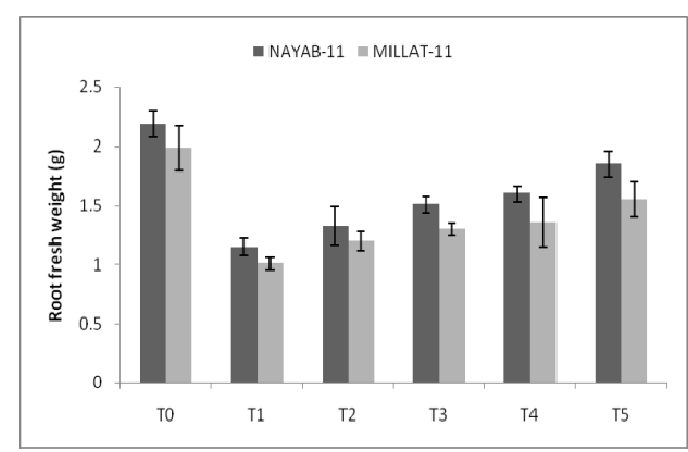

(b)

Figure 2. Effect of different levels of $\mathrm{K}_{2} \mathrm{SO}_{4}$ on fresh weight of shoots (a) and roots (b) of two wheat genotypes at $150 \mathrm{mM}$ of $\mathrm{NaCl}$ stress

Data indicate that root fresh weight was observed lower in MILLAT-11 and higher in NAYAB-11 under saline conditions. But maximum growth was observed in controlled than in other treatments of potash and salinity conditions (Figure 2b).

Potassium fertilizer at $200 \mathrm{mM}$ increased the biomass of both genotypes i.e. NAYAB-11 and MILLAT-11 under salinity conditions. Application of potassium exhibited different effect in this attributes due to different levels of potassium under salt stress. Reduction of root fresh weight (60.6\%) were observed by the application of $150 \mathrm{mM}$ sodium chloride stress only but this percentage was reduced to $17.5 \%$ at $200 \mathrm{mM}$ of $\mathrm{K}_{2} \mathrm{SO}_{4}$ in both genotypes in saline environments (Figure 2b). Interaction between varieties and treatment indicate non significant behavior, because treatments of potassium and salinity affected the crop non-significantly on root fresh weights (Table 2). Several reports are available in agreement of the present studies that fresh biomass production reduced by the salinity stress as compared to non saline conditions (Kausar et al., 2012; Akhtar et al., 2013; Kausar \& Gull, 2014). However use of fertilizers in stressed conditions proved better for the high biomass production of crops (Ashraf et al., 2013; Tzortzakis, 2010).

\subsection{Shoot and Roots Dry Weight}

Results showed that maximum growth was observed at controlled conditions in both genotypes. Salinity affected the wheat crop significantly (Table 2). Salinity reduced the shoot dry weight in both genotypes. But more reduction was observed in MILLAT-11 followed by NAYAB-11. Addition of potassium slightly increases shoot dry weight under sodium chloride stress (Figure 3a). At $200 \mathrm{mM} \mathrm{K}_{2} \mathrm{SO}_{4}$ crop grow better than other treatments of potassium under saline environment. At $150 \mathrm{mM} \mathrm{NaCl}$, maximum reduction was observed $66.6 \%$ followed by $53.7 \%, 42.4 \%, 36.6 \%$ and $17.08 \%$ in other levels of potassium in both NAYAB-11 and MILLAT-11 genotypes of wheat (Figure 3a). 


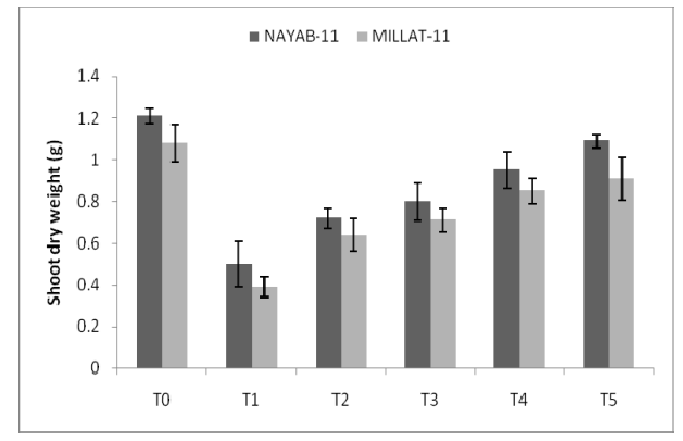

(a)

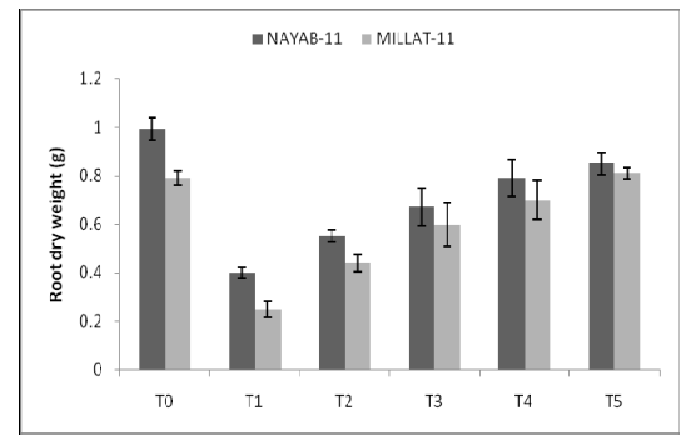

(b)

Figure 3. Effect of different levels of $\mathrm{K}_{2} \mathrm{SO}_{4}$ on dry weight of shoots (a) and roots (b) of two wheat genotypes at $150 \mathrm{mM}$ of $\mathrm{NaCl}$ stress

Varieties $\mathrm{x}$ treatment interaction were showed non significant results. Under salt stress conditions, both varieties of wheat had lower root length. However, both NAYAB-11 and MILLAT-11 varieties responded positively to potash fertilizer under salinity conditions, and it also increased significantly with increasing level of potassium (Table 2). Data showed that maximum root dry weight was recorded in MILLAT-11 than NAYAB-11 genotypes of wheat in controlled treatment. Salinity decreased the biomass and number of tillers of wheat plant. Application of different levels of potassium sulphate mitigates the negative effect of salt stress and increased the plant growth under stressed conditions (Figure 3b). At $150 \mathrm{mM}$ salt stress and $200 \mathrm{mM}$ potassium sulphate, higher and lower reduction $64.5 \%$ followed by $22.5 \%$ in MILLAT-11 was found respectively (Figure $3 \mathrm{~b}$ ).

Varieties $\mathrm{x}$ treatment interaction showed non significant behavior on root dry weight, because results showed that treatment of both salinity and potassium affected the crop non significantly in NAYAB-11 and MILLAT-11 genotypes (Table 2). Salt stressed environments reduced the plant growth and development (Ashraf et al., 2003), so overall the plant dry biomass has negatively affected by salt stress (Kausar et al., 2014). However, Dry biomass has been increased by the presence of potassium fertilizer. Adequate potassium fertilizer utilization can increase the total dry mass production of plants under salt and drought stress as compare to lower concentrations of potash fertilizer (Wang et al., 2013).

\subsection{Sodium of Roots and Shoots ( $\mathrm{mg} / \mathrm{g}$ dry wt.)}

Analysis data indicate that salt stress increased $\mathrm{Na}^{+}$contents significantly of both genotypes. $\mathrm{Na}^{+}$contents were more pronounced in MILLAT-11(30 mg/g d.wt.) and least values were observed in NAYAB-11 (26 mg/g d.wt.) under saline conditions of both shoots and roots (Figures 4a, 4b) However, very low quantity of sodium was observed in controlled in both genotypes NIAB-11 and MILLAT-11 respectively. Application of potassium fertilizer decreases the $\mathrm{Na}^{+}$contents in NAYAB-11 than MILLAT-11, because NAYAB-11 was found to be more resistant to saline environment (Figures 4a, 4b).

Varieties and treatment interaction showed non significant behavior, because different treatment of $\mathrm{K}$ and $\mathrm{NaCl}$ affected the plant non-significantly in sodium contents of roots and shoots in both NAYAB-11 and MILLAT-11 genotypes (Table 3). Under salt stressed conditions, both varieties of wheat had lower shoot contents. However, both NAYAB-11 and MILLAT-11 varieties responded positively to potash fertilizer less than $150 \mathrm{mM} \mathrm{NaCl}$. It also increased with increasing level of potassium. In the salt stress conditions there is more uptake and accumulation of toxic ions than essential nutrients in the plant tissue, (Kausar et al., 2012) as a result there is more negative value of water potential in leaf tissues which decreases the rate of photosynthesis rate as a consequence this decrease the plant growth and productivity (Irshad et al., 2002; Ali et al., 2012). Salt affected soils requires nutrients particularly potassium that play an important role in plant growth and germination. As a result the plant development depends upon the availability of suitable amounts of potassium sulphate, which increases crops overall productivity (Wang et al., 2013). 


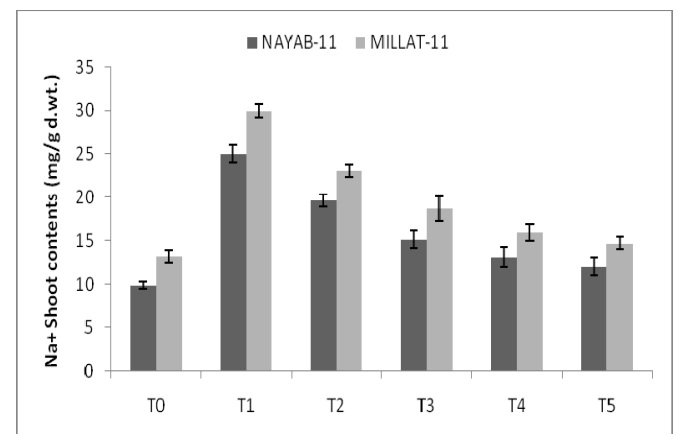

(a)

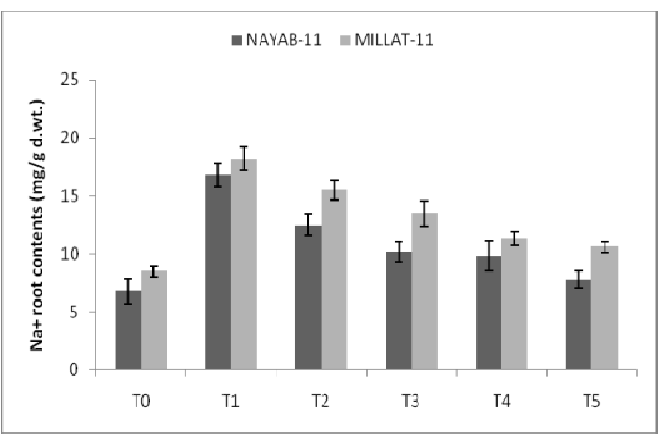

(b)

Figure 4. Effect of different levels of $\mathrm{K}_{2} \mathrm{SO}_{4}$ on sodium contents of shoots (a) and roots (b) of two wheat genotypes at $150 \mathrm{mM}$ of $\mathrm{NaCl}$ stress

\subsection{Potassium Contents in Roots and Shoots ( $\mathrm{mg} / \mathrm{g}$ dry wt.)}

Analysis of variance data revealed that under the influence of salt stress at different growth stages affected the uptake of potassium significantly. Salinity at either stage decreases the potassium contents in both genotypes of wheat. Maximum reduction was observed in MILLAT $11(9.33 \mathrm{mg} / \mathrm{g}$ dry weight) and least in NAYAB 11(12.16 $\mathrm{mg} / \mathrm{g}$ dry weight) as compared to controlled. Application of potassium increased the concentration of potassium in plants under salt stressed environment but minimum increased was observed in MILLAT 11 (Figures 5a, 5b). Maximum reduction at $150 \mathrm{mM} \mathrm{NaCl}$ was observed $37.5 \%$ and minimum reduction was recorded at $200 \mathrm{mM}$ $\mathrm{K}_{2} \mathrm{SO}_{4}$ and $150 \mathrm{mM} \mathrm{NaCl}$ (Figure 5a, 5b). On the uptake of potassium interaction between genotypes and treatment was non significant because both genotypes behaved non significantly (Table3). Under salt stressed conditions, both varieties of wheat had lower shoot $\mathrm{Na}^{+}$contents. However, both NAYAB-11 and MILLAT-11 varieties responded positively to potash fertilizer less than $150 \mathrm{mM} \mathrm{NaCl}$. It also increased with increasing level of potassium. Potassium is macro-nutrient and its availability controls many biochemical and physiological responces in plants (Wang et al., 2013). Presence of potassium plays essential roles in various enzyme activation, photosynthesis, proteion synthesis, osmoregulation, energy transfer, stomatal movement, cation-anion balance and stress resistance (Wang et al., 2013).

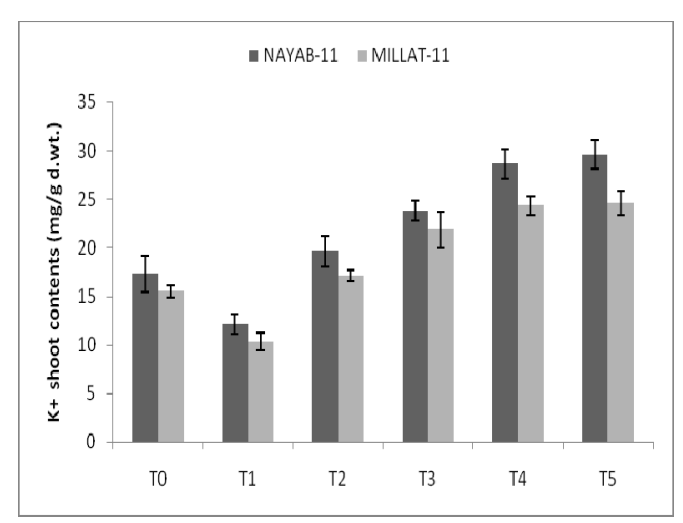

(a)

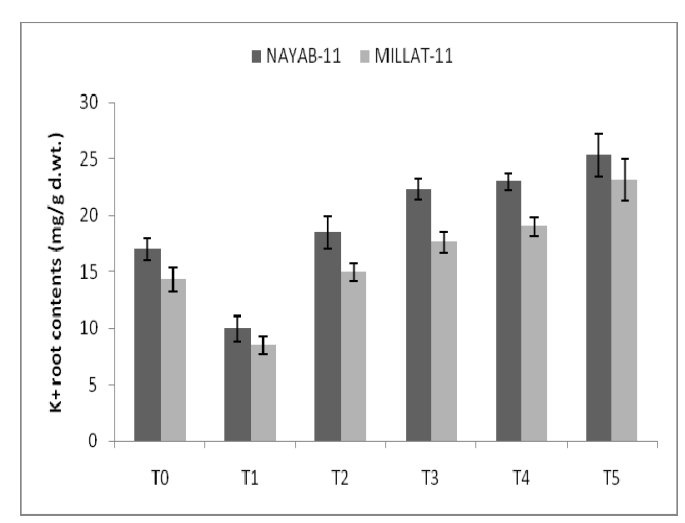

(b)

Figure 5. Effect of different levels of $\mathrm{K}_{2} \mathrm{SO}_{4}$ on potassium contents of shoots (a) and roots (b) of two wheat genotypes at $150 \mathrm{mM}$ of $\mathrm{NaCl}$ stress 
Table 3. Mean squares from analysis of variance (ANOVA) of data for different levels of $\mathrm{K}_{2} \mathrm{SO}_{4}$ on length, fresh and dry weights of both shoots and roots of two wheat genotypes at $150 \mathrm{mM}$ of $\mathrm{NaCl}$ stress

\begin{tabular}{cccccc}
\hline SOV & Df & $\begin{array}{c}\text { Sodium of } \\
\text { Shoots }\end{array}$ & $\begin{array}{c}\text { Sodium of } \\
\text { roots }\end{array}$ & $\begin{array}{c}\text { Potassium of } \\
\text { shoots }\end{array}$ & $\begin{array}{c}\text { Potassium of } \\
\text { roots }\end{array}$ \\
\hline Treatment & 5 & $107.950^{* * *}$ & $49.5569^{* * *}$ & $229.583^{* * *}$ & $172.624^{* * *}$ \\
Variety & 1 & $28.444^{* *}$ & $31.1736^{* *}$ & $78.028^{* * *}$ & $73.674 * * *$ \\
T x V & 5 & $4.244 \mathrm{~ns}$ & $0.569 \mathrm{~ns}$ & $3.125^{* *}$ & $3.490^{* *}$ \\
Error & 24 & 2.472 & 2.5278 & 0.569 & 0.917 \\
Total & 35 & & & & \\
\hline
\end{tabular}

$*, * *, * * *,=$ Significant at $0.05,0.01, .001 \%$, respectively, $\mathrm{ns}=$ =non-significant.

\subsection{Nitrogen Contents of Roots and Shoots ( $\mathrm{mg} / \mathrm{g}$ dry wt.)}

The analyzed data indicate that salinity affected wheat nitrogen contents significantly. Significant effect was observed by nitrogen uptake in both genotypes of shoots (Figures 6a, 6b). Maximum uptake of nitrogen in shoot was recorded in controlled treatments in NAYAB-11 than MILLAT-11. Addition of potassium fertilizer increased the nitrogen uptake on the concentration of nitrogen. Minimum and maximum effect was showed at $50 \mathrm{mM}$ and $200 \mathrm{mM} \mathrm{K}_{2} \mathrm{SO}_{4}$ under saline environment in two genotypes of wheat (Figures 6a, 6b). At $150 \mathrm{mM} \mathrm{NaCl}$ maximum reduction $52 \%$ was observed in shoots, however minimum reduction $24 \%$ was observed at $200 \mathrm{mM}$ $\mathrm{K}_{2} \mathrm{SO}_{4}$ in both genotypes of wheat. Similar trend was also recorded in roots of NAYAB-11 and MILLAT-11 by the application of potassium under salinity stress. Interaction between treatment $\mathrm{x}$ potassium was showed non significant effect on nitrogen contents of both roots and shoots inNAYAB-11 and MILLAT-11 genotypes (Table 4). These findings that nitrogen contents are decreased in stressed environments is also proved by Ashraf et al. (2003) and Kausar and Gull (2014). Similar findings are also depicted by Kausar et al. (2014) that salt stress negatively effect the plant growth and development in such a way that many metabolic processes bcomes hinders because of nitrogen deficiency in plants. It is also reported that potassium is essential nutrients and growth of plants increased in the potassium fertilizer and there is more absorption of nitrogen contents by the use of fertilizer as investigated by Tzortzakis (2010) and Ashraf et al. (2013).

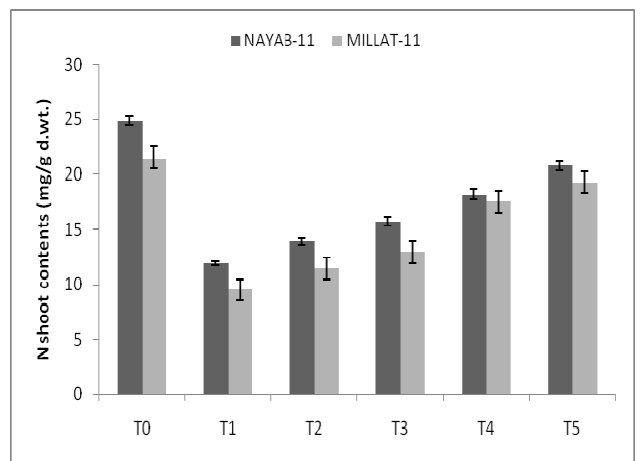

(a)

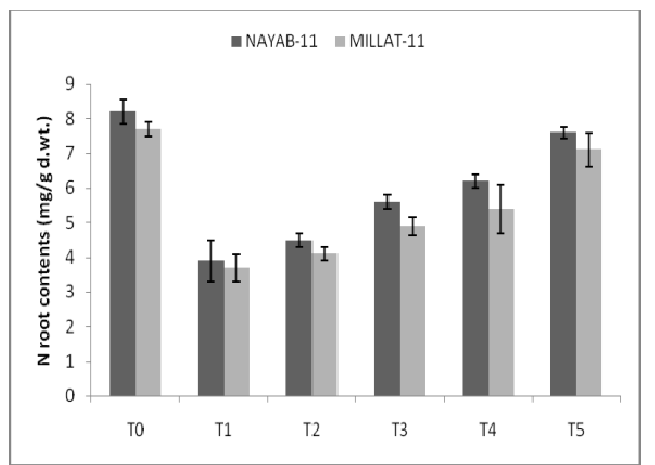

(b)

Figure 6. Effect of different levels of $\mathrm{K}_{2} \mathrm{SO}_{4}$ on nitrogen contents of shoots (a) and roots (b) of two wheat genotypes at $150 \mathrm{mM}$ of $\mathrm{NaCl}$ stress

\subsection{Calcium Contents of Shoots and Roots ( $\mathrm{mg} / \mathrm{g}$ dry wt.)}

Analysis data showed that these contents is present higher in controlled than salinity in both genotypes of wheat. At $150 \mathrm{mM}$ of salt stress germination percentage reduced significantly. Maximum reduction due to salinity observed in MILLAT-11 genotypes than NAYAB-11 genotypes. However, application of potash increased the calcium contents under saline conditions, but this increased not more than in controlled both in shoots and roots (Figures 7a, 7b). Higher calcium contents are present at $200 \mathrm{mM} \mathrm{K}_{2} \mathrm{SO}_{4}$ in NIAB-11 (25 mg/g dry wt.) followed by MILLAT-11 (23 mg/g dry wt.) at $150 \mathrm{mM} \mathrm{NaCl}$ stress than other treatments of potassium and sodium. 
Salinity reduced these contents higher in MILLAT-11 than NAYAB-11 in both roots and shoots (Figures 7a, 7b). Similar response of treatment on wheat varieties was also recorded in calcium contents of roots. Maximum and minimum reduction $46.1 \%$ and $11.5 \%$ in calcium contents of roots and shoots was recorded at $150 \mathrm{mM} \mathrm{NaCl}$ and $200 \mathrm{mM} \mathrm{K} 2 \mathrm{SO} 4+150 \mathrm{mM} \mathrm{NaCl}$ respectively in both genotypes of wheat (Figures 7a,7b). Interaction between varieties and treatment was showed non significant behavior in calcium contents of both roots and shoots in MILLAT-11 and NAYAB-11 (Table 4). These results are in accordance with Ashraf et al. (2013) and Kausar \& Gull (2014). It is now well established fact that application of $\mathrm{NaCl}$ stress reduced plant growth because of lowering in water potential, turgor potential, more absorption of toxic ions which cause the ions toxicity and less uptake of essential nutrients like potassium, calcium and phosphorus both in shoots and roots (Gupta \& Huang, 2014).

Table 4. Mean squares from analysis of variance (ANOVA) of data for different levels of $\mathrm{K}_{2} \mathrm{SO}_{4}$ on $\mathrm{Nitrogen}$, calcium and phosphorus both shoots and roots of two wheat genotypes at $150 \mathrm{mM}$ of $\mathrm{NaCl}$ stress

\begin{tabular}{cccccccc}
\hline SOV & df & $\begin{array}{c}\text { Nitrogen of } \\
\text { shoots }\end{array}$ & $\begin{array}{c}\text { Nitrogen of } \\
\text { roots }\end{array}$ & $\begin{array}{c}\text { Calcium of } \\
\text { shoots }\end{array}$ & $\begin{array}{c}\text { Calcium of } \\
\text { roots }\end{array}$ & $\begin{array}{c}\text { Phosphorus } \\
\text { of shoots }\end{array}$ & $\begin{array}{c}\text { Phosphorus } \\
\text { of roots }\end{array}$ \\
\hline Treatment & 5 & $65.6444 * * *$ & $16.7083 * * *$ & $16.1111 \mathrm{~ns}$ & $142.778 \mathrm{~ns}$ & $3.00144 \mathrm{~ns}$ & $1.37761 * *$ \\
Variety & 1 & $7.84 * *$ & $1.4803 * *$ & $25.000 \mathrm{~ns}$ & $2.778 \mathrm{~ns}$ & $0.72818 \mathrm{~ns}$ & $2.94694 * *$ \\
TxV & 5 & $0.2673 \mathrm{~ns}$ & $38.3333 \mathrm{~ns}$ & $62.778 \mathrm{~ns}$ & $0.02001 \mathrm{~ns}$ & $0.53094 \mathrm{~ns}$ \\
Error & 24 & 0.6819 & $83.3333 \mathrm{~ns}$ & 136.111 & 1.45415 & 0.32556 \\
Total & 35 & & & & &
\end{tabular}

$*, * *, * * *,=$ Significant at $0.05,0.01, .001 \%$, respectively, ns=non-significant.

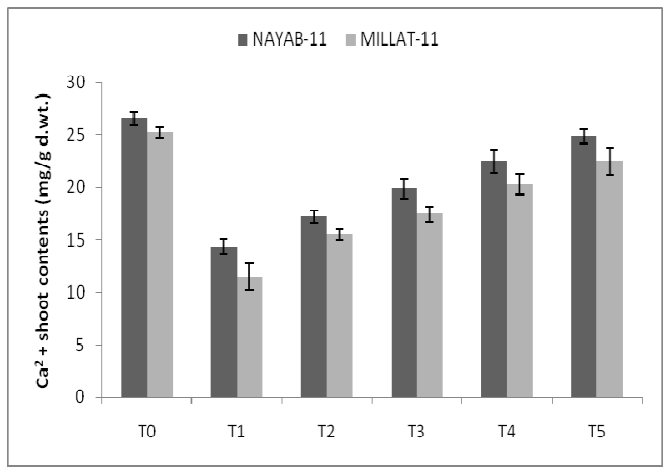

(a)

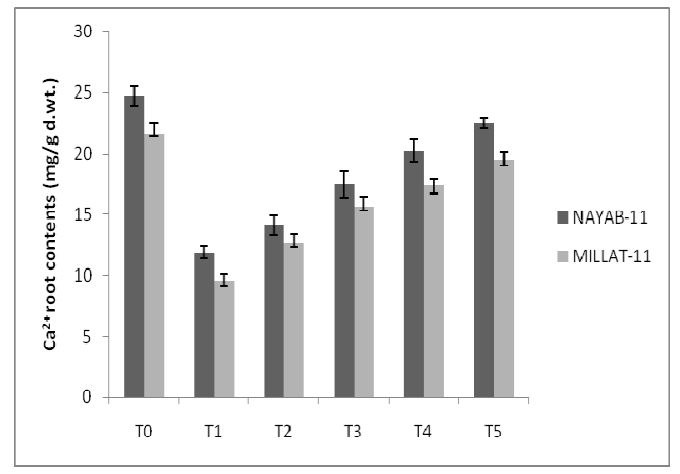

(b)

Figure 7. Effect of different levels of $\mathrm{K}_{2} \mathrm{SO}_{4}$ on calcium contents of shoots (a) and roots (b) of two wheat genotypes at $150 \mathrm{mM}$ of $\mathrm{NaCl}$ stress

\subsection{Phosphorous Contents of Roots and Shoots ( $\mathrm{mg} / \mathrm{g}$ dry wt.)}

Data indicate that phosphorous concentration is affected by salinity and depends on the concentration of salinity. It also observed that adverse effect of salt stress significant on the uptake of phosphorous. Maximum phosphorous contents were observed at controlled conditions in NAYAB-11 (5.5 mg/g d.wt.) genotypes than MILLAT-11 (5.1 mg/g dry wt.) (Figures 8a, 8b). Addition of potassium slightly increase the concentration of phosphorous under salt stressed in both MILLAT 11 and NAYAB 11. But minimum uptake was recorded in MILLAT-11 and maximum in NAYAB-11. Highest reduction (54.5\%) of phosphorous at $150 \mathrm{mM}$ of salt stress was observed, however, lowest reduction (18.18\%) was observed at $200 \mathrm{mM} \mathrm{K}_{2} \mathrm{SO}_{4}$ under saline conditions (Figure 8a, 8b). Similar effect of salinity and potassium was observed in phosphorous contents of roots and shoots in both varieties of wheat (Figures $8 \mathrm{a}, 8 \mathrm{~b}$ ).

The phosphorus contents decreased under salt stressed soils. However, by the use of potassium sulphate this reduction in phosphorus contents was diminished. Both genotypes of wheat showed non significant effect, because interactive effect between varieties and treatments were non significant (Table 4). There is need of 
abiotic stress tolerance crops for high productivity. Different strategies has been adopted to cope the situation Techniques that have vital importance to reduce the effect of salinity such as use of fertilizers, breeding of new plant varieties, exogenous use of plant osmo protectant and growth regulators and genetically modified crop production (Ashraf et al., 2013).

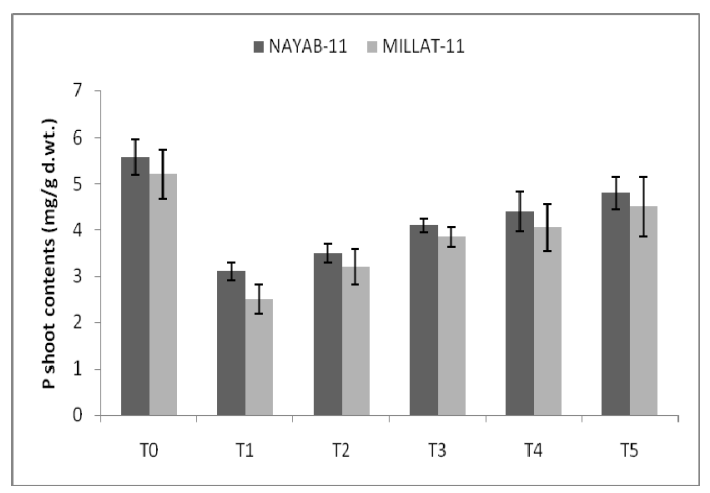

(a)

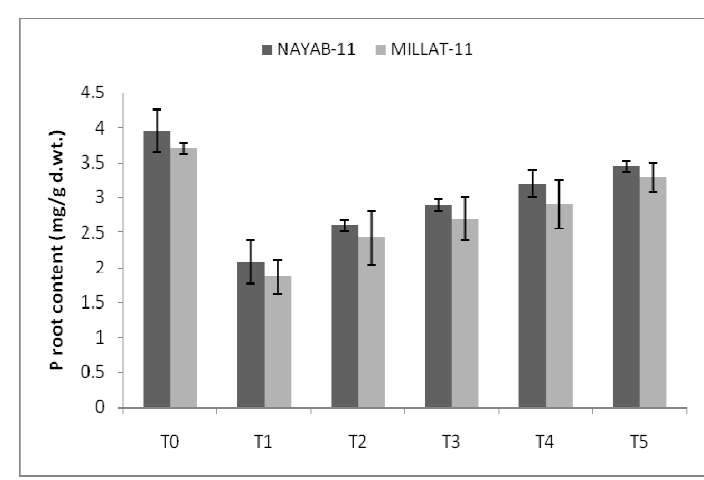

(b)

Figure 8. Effect of different levels of $\mathrm{K}_{2} \mathrm{SO}_{4}$ on phosphorus contents of shoots (a) and roots (b) of two wheat genotypes at $150 \mathrm{mM}$ of $\mathrm{NaCl}$ stress

Potassium is macronutrients that used in the form of sulphate of potash (SOP) as $\mathrm{K}_{2} \mathrm{SO}_{4}$ Under stressful environment, addition of potash fertilizers increased the growth and yield (Hussain et al., 2013). In present study, potassium was applied to alleviate the adverse effect of salinity and there was significant increase in lengths, fresh and dry weights of shoots and roots in both genotypes. The fertilizers showed positive effect on growth and development under salinity conditions. Similar results were reported that growth of rice and wheat crop increased significantly in response to application of potash under stress conditions (Hussain et al., 2013). It may be due to increase rate of photosynthesis as depicted that the rate of photosynthesis becomes enhanced by the application of potassium in stressed environment (Ali et al., 1999). Similar investigations were also obtained by Rashid et al. (2001).

In present study as there was also significantly increase in nutrients uptake like potassium, calcium, nitrogen and phosphorus by the application of fertilizer in the stressed conditions in both genotypes. This increase was more pronounced effect as the concentrations of fertilizer increases in both the genotypes reverse of that when these essential ions were decreased with the application of salinity only in wheat. Analysis of variance of data showed that $\mathrm{N}, \mathrm{P}$, and $\mathrm{K}$ were reduced at $150 \mathrm{mM} \mathrm{NaCl}$, while application of potassium at $200 \mathrm{mM}$ progressively increased the contents of $\mathrm{N}, \mathrm{P}$, and $\mathrm{K}$ in both varieties of wheat. Both varieties responded positively by the application of potassium. The concentrations of $\mathrm{N}, \mathrm{P}$ and $\mathrm{K}$ in the roots and shoots were affected significantly due to salinity in both genotypes of wheat. In both roots and shoots, application of potassium increased these inorganic ions. Potassium application as $\mathrm{K}_{2} \mathrm{SO}_{4}$ increased nitrogen concentration to some extent (Gupta \& Haung, 2014). These facts indicate that $\mathrm{SO}_{4}^{-2}$ play an important role to the formation of some proteins which ultimately has positive effect on plant growth. Sulphur is an important structural constituent of some amino acids such as cysteine (Lee et al. 2009). These results are also obtained by Rashid et al. (2001) and confirmed by Gupta and Haung (2014).

The present research works indicate that $\mathrm{K}$ source increased the growth and development of plants under saline conditions. It is suggested that potassium sulphate may be used to alleviate the effect of salinity in crops which grow on stressed areas of the world.

\section{References}

Akhtar, J., Ahmad, R., Ashraf, M. Y., Tanveer, A., Waraich, E. A., \& Oraby, H. (2013). Influence of exogenous application of salicylic acid on salt stressed mung bean (Vignaradiata): growth and nitrogen metabolism. Pakistan Journal of Botany, 45, 119-125.

Ali, A., Basra, S. M. A., Hussain, S., \& Iqbal, J. (2012). Increased Growth and Changes in Wheat Mineral Composition through Calcium Silicate Fertilization under Normal and Saline Field Conditions. Chilean J. Agric. Res., 72(1). 
Ali, C. K., Javed, M., \& Javaid, M. A. (1999). Growth promotion of wheat by potassium application in saline soils. J. Ind. Soc. Soil Sci., 47, 510-513.

Ashraf, M. Y., \& Sarwar, G. (2002). Salt tolerance potential in some members of Brassiaceae. Physiological studies on water relations and mineral contents (pp. 237-245). In prospects for saline agriculture. Academic Publishers Netherlands.

Ashraf, M. Y., Rafique, N., Ashraf, M., Azhar, N., \& Marchand, M. (2013). Effect of supplemental potassium (K ${ }^{+}$) on growth, physiological and biochemical attributes of wheat grown under saline conditions. Journal of Plant Nutrition, 36, 443-458. http://dx.doi.org/10.1080/01904167.2012.748065

Ashraf, M., Afzal, M., Ahmad, R., \& Ali, S. (2011). Growth and yield components of wheat genotypes as influenced by potassium and farm yard manure on a saline sodic soil. Soil and Environment, 30, 115-121.

Ashraf, M., Kausar, A., \& Ashraf, M. Y. (2003). Alleviation of salt stress on growth of pearl millet (Pennisetum glaucumm L. (R. Br.) by pre-sowing treatment of seeds with chilling, heating, distilled water, $\mathrm{NaCl}$ and PEG. J. Agron., 23(3), 253-259.

Bray, E. A., Serres, J. B., \& Weretilny, K. (2000). Responses to abiotic stresss. In B. Buchanan, W. Gruissem \& R. Jones (Eds.), Biochemistry and molecular biology of plants. Plant Physiology, 1158-1203.

Bremner, J. M. (1965). Total nitrogen and inorganic forms of nitrogen. In C. A. Black (Ed.), Methods of Soil Analysis (Vol. 2, pp. 1149-1237). American Soc. Agron., Madison, Wisconsin.

Ebrahimi, R. F., Rahdari, P., Vahed, M. S., \& Shahinrokhsar, P. (2012). Rice response to different methods of potassium fertilization in salinity stress condition. International Journal of Agricultural and Crop Science, 4, 798-802.

Golldack, D. Q., Michalowski, F., Kamasani, U. R., \& Bohnert, H. J. (2003). Salinity stress tolerant and sensitive rice regulate AKT1- type potassium channel transcript differently. PIant Mol Biology, 51, 71-81. http://dx.doi.org/10.1023/A:1020763218045

Gupta, B., \& Haung, B. (2014). Mechanisim of salinity tolerance in plants: Physiollogical, biochemical, and molecular characterization. International Journal of Genomics, 2014, Article ID 701596. http://dx.doi.org/10.1155/2014/701596

Han, L., Gao, Y., \& Li, D. (2014). Ion Uptake in Tall Fescue as Affected by Carbonate, Chloride, and Sulfate Salinity. PLOS ONE, 9(3), e91908. http://dx.doi.org/10.1371/journal.pone.0091908

$\mathrm{Hu}, \mathrm{Y} .$, \& Schmidhalter, U. (2005). Drought and salinity,a comparison of their effects on mineral nutrition of plants. Journal of Plant Nutrition and Soil Science, 168, 541-549. http://dx.doi.org/10.1002/jpln.200420516

Hussain, Z., Khattak, R. A., Irshad, M., \& Eneji, A. E. (2013). Ameliorative effect of potassium sulphate on the growth and chemical composition of wheat (Triticum aestivum L.) in salt-effected soils. J. Soil Sci. Plant Nutr., 13(2). http://dx.doi.org/10.4067/S0718-95162013005000032

Idrees, S., Qureshi, M. S., Ashraf, M. Y., Hussain, M., \& Naveed, N. H. (2004). Infuence of sulphate of potash and farm yard manure on sugarcane grown under salt stress. Pakistan Journal of Life Social Science, 2, 321-328.

Irshad, M., Honna, T., Eneji, A. E., \& Yamamoto, S. (2002). Wheat response to nitrogen source under saline conditions. Journal of Plant Nutrition, 25(12), 2603-2612. http://dx.doi.org/10.1081/PLN-120015525

Jackson, M. L. (1962). Soil chemical analysis. Publisher, Constable and company, England.

Jessop, R. S., \& Stewart, L. W. (1983). Effect of crop residues, soil type and temperature on emergence and early growth on wheat. Plant and Soil, 74, 101-109. http://dx.doi.org/10.1007/BF02178745

Kausar, A., \& Gull, M. (2014). Nutrients uptake and growth analysis of four sorghum (Sorghum bicolor L.) genotypes exposed to salt stress. Pensee Journal, 76(4).

Kausar, A., Ashraf, M. Y., \& Niaz, M. (2014). Some physiological and genetic determinants of salt tolerance in sorghum (Sorghum bicolor (L.) Moench): Biomass production and nitrogen metabolisim. Pakistan Journal of Botany, 46(2), 515-519.

Kausar, A., Ashraf, M. Y., Ali, I., Niaz, M., \& Abbass, Q. (2012). Evaluation of sorghum varieties/lines for salt tolerance using physiological indecies as screening tool. Pakakistan Journal of Botany, 44(1), 47-52.

Khan, A. M., Islam, E., Shirazi, M. U., Mumtaz, S., \& Mujtaba, S. M. (2010). Physiological response of various wheat genotypes to salinity. Pakistan Journal of Botany, 42, 3497-3505. 
Khan, M. H., \& Panda, S. K. (2008). Alterations in root lipid peroxidation and antioxidant responses in two rice cultivars under salinity stress. Acta Physiology Plant, 30, 89-91.

Kosovak, Prasil, I. T., \& Vitamas, P. (2013). Protein Contribution to Plant Salinity Response and Tolerance Acquisition. Int. J. Mol. Sci., 14, 6757-6789. http://dx.doi.org/10.3390/ijms14046757

Krauss, A. (2003). Crop insurance against stress with adequate potash (pp. 28-30). Presented at the AFA 9th International Annual Conference, Cario.

Lee, B. V., Dikiy, A., Kim, H. Y., \& Gladyshev, V. N. (2009). Functions and evolution of selenoprotein methionine sulfoxide reductases. Biochimica et Biophysica Acta (BBA), 1790(11), 1471-1477. http://dx.doi.org/10.1016/j.bbagen.2009.04.014

Mesbah, E. A. E. (2009). Effects of irrigation regimes and foliar spraying of potassium on yield, yield components and water use efficiency of wheat in sandy soils. World Journals of Agricultural Sciences, 5, 662-669.

Noaman, M. N. (2004). Effect of potassium and nitrogen fertilizers on the growth and biomass of some halophytes grown under high levels of salinity. Journal of Agronomy, 3, 25-30. http://dx.doi.org/10.3923/ja.2004.25.30

Rashid, H. H., Ranjha, A. M., Mehdi, S. M., \& Saifullah. (2001). Relative efficiency of muriate and sulphate of potash for wheat. International Journal of Agricultural Biology, 3, 403-405.

Razmjoo, K., Heydarizadeh, P., \& Sabzalian, M. R. (2008). Effect of salinity and drought stresses on growth parameters and essential oil content of Matricaria chamomila. Int. J. Agri. Biol., 10, 451-4.

Saifullah, A. M., Ranjha, M., Yaseen, M., \& Akhtar, M. E. (2002). Response of wheat to potassium fertilization under field conditions. Pakistan Journal of Agricultural Science, 39(4), 91-93.

Steel, R. G. D., Torrie, J. H., \& Dickey, D. A. (1997). Principles and Procedures of Statistics, A biometrical approach (pp. 178-182). McGraw Hill Co., New York.

Tzortzakis, N. G. (2010). Potassium and calcium enrichment alleviate salinity-induced stress in hydroponically grown endives. Hort. Sci. (Prague), 37, 155-162.

Wang, M. Zheng, Q., Shen, Q., \& Guo, S. (2013). The critical role of potassium in plant stress response. International Journal of Molecular Sciences, 14, 7370-7390. http://dx.doi.org/10.3390/ijms14047370

Wenxue, W., Bilsborrow, P. E., Hooley P., Fincham, D. A., Lombi, E., \& Froster, B. P. (2003). Salinity induced differences in growth, ion distribution and partitioning in Barley between the cultivar Maythrope and its derived mutant Golden Promise. Plant Soil, 250, 183-191. http://dx.doi.org/10.1023/A:1022832107999

Wolf, B. (1982). A comprehensive system of leaf analysis and its use for diagnosing crop nutrient status. Communications in Soil Science and Plant Analysis, 13, 1035-1059. http://dx.doi.org/10.1080/00103628209367332

\section{Copyrights}

Copyright for this article is retained by the author(s), with first publication rights granted to the journal.

This is an open-access article distributed under the terms and conditions of the Creative Commons Attribution license (http://creativecommons.org/licenses/by/3.0/). 